\title{
A Model of the Global and Institutional Antecedents of High-Level Corporate Environmental Performance
}

\author{
MARK P. SHARFMAN \\ TERESA M. SHAFT \\ LASZLO TIHANYI \\ The University of Oklahoma
}

Stories of firms that exceed local compliance requirements in their environmental performance appear routinely. However, we have limited theoretical explanations of what propels these firms to exceed compliance. Our theory suggests that global competitive and institutional pressures lead multinational firms to develop highlevel, environmental management systems (EMS) that make them more competitive. For economic and other reasons, select firms make the choice to rationalize their collective environmental performance to the highest common denominator rather than the lowest. Regulations around the world differ widely and are a moving target in many settings. The need to comply with such myriad, shifting rules leads to firms creating EMS to help stay ahead of regulations worldwide. Using institutional and internationalization theories as our basis, we offer a propositional model concerning global competitive/institutional pressures and their effects on corporate environmental performance. We conclude the paper with a discussion of the implications of the model.

Keywords: natural environment; globalization; institutional theory; environmental performance; multinational enterprises

AUTHORS' NOTE: The authors wish to thank Petra Christmann, Jeanne Logsdon, and several reviewers for their helpful comments on this and earlier drafts of this article. The efforts on this project by the first and second authors were supported in part by National Science Foundation grant no. 9976530 and Michael F. Price College of Business Alley Rayonier and Summer Fellowship grants.

BUSINESS \& SOCIETY, Vol. 43 No. 1, March 2004 6-36 DOI: $10.1177 / 0007650304262962$

(c) 2004 Sage Publications 
It really doesn't matter what they do in Washington in trying to reduce environmental regulations. We are a global company and play by a global set of rules.

—Dr. Braden Allenby, Vice President, Environment, Health and Safety, AT\&T (personal communication, June 22, 1996)

Worldwide, GM is integrating its environmental management systems, based on ISO 14001 specifications, into a common system. These systems include GM's Environmental Performance Criteria (EPC) which assist our business units in protecting human health and the environment when regulatory programs do not clearly address these goals.

- General Motors (2002)

Bristol-Meyers Squibb's internal standards go beyond legal compliance and apply to all of our facilities worldwide. The EHS [Environmental Health And Safety] Codes of Practice set forth Bristol-Meyer Squibb's EHS requirements for all of our business functions and facilities around the world

-Bristol-Myers Squibb (2003)

The above quotes suggest an intriguing trend in worldwide business practice-the globalization of corporate environmental performance. However, it is not clear why this trend has occurred. In this article, we examine the linkage between environmental performance and firm globalization. The globalization of environmental performance is but one component of the general trend toward the globalization of business. Luo (1999) reports over \$630 billion in total foreign direct investment in 1995 alone (his last year of available data). Data gleaned from recent U.S. Department of Commerce and Organization for Economic Cooperation and Development (OECD) publications suggest this figure may have exceeded $\$ 1$ trillion in 2002. The push for globalization is not something that many firms can ignore. Even firms that choose not to engage in business outside the borders of their home countries are likely to face competitors who have made such a choice. As such, even in a local market, a firm may face issues of globalization. When firms develop strategies that take them outside of their domestic borders, they face two sets of pressures: the need for global integration (homogenization) and the need for responsiveness to local markets (e.g., Bartlett \& Ghoshal, 1989; Prahalad \& Doz, 1987). These are not mutually exclusive forces (Ghoshal \& Nohria, 1993). Rather, firms can face high or low levels of each force simultaneously. 
The pressures for globalization and local market responsiveness are even more apparent in the case of environmental performance. Efficient environmental management systems (EMS) require compliance with environmental regulations, which can vary substantially. This variation further increases the organizational complexity of international business operations. Standardization across the worldwide operations of multinational firms is also challenging. Increasingly, however, multinational enterprises (MNEs) choose a global approach to environmental management consistent with the quotations at the start of this article. Such global approaches lead to overall better environmental performance for firms as they rationalize their systems to the most stringent regulatory schema rather than the weakest.

In the remainder of this article, we present the following: First, we describe the global and institutional pressures that push multinational firms toward higher levels of environmental performance. These pressures include forces that stem from the multiplicity of regulatory trajectories that firms face in the complex global context, from the institutional forces of societal "green" movements throughout the world, and from those forces pushing firms specifically toward life-cycle-oriented environmental management (LCOEM). As part of our review of the regulatory pressures, we examine existing literature that refutes what is called the pollution haven hypothesis that suggests MNEs seek out low-regulation countries so they do not have to worry about their environmental performance. From our review of the three sets of forces, we develop a propositional model of the antecedents of high-level environmental performance by multinationals. We conclude the article with a discussion of the implications of our model and some ideas for future research.

\section{GLOBAL AND INSTITUTIONAL \\ PRESSURES FOR HIGH-LEVEL ENVIRONMENTAL PERFORMANCE}

Environmental issues present a unique challenge to the firm in terms of the global integration versus local responsiveness dilemma. In this article, we examine the effects of global and institutional pressures on firms regarding their environmental performance and how these pressures drive firms to exceed the minimum standards of environmental regulatory compliance everywhere they operate - particularly in those countries with the most stringent regulations. By meeting or exceeding compliance everywhere they operate, firms will, by necessity, reach high levels of overall 
environmental performance. This idea is consistent with Margretta (1997) as well as Rugman and Verbeke (1998a) who argued specifically,

MNEs design their production processes according to best global practices. MNEs operate in accordance with the most stringent environmental regulations prevailing in the relevant countries where they operate. (pp. 371-372)

The more that firms adopt a global approach to their overall business, that is, one where they implement (perhaps with only modest local modifications) a consistent strategy worldwide, the more applicable our arguments in this article become. Perlmutter's (1969) classification of multinational firms describes three approaches that firms take as they internationalize-geocentric, polycentric, and ethnocentric. Geocentric firms are ones that develop "a global, cosmopolitan orientation that is not tied [necessarily] to any particular national identity" (Kostova \& Zaheer, 1999, p. 73). It is such global (geocentric) firms that we argue are most likely to achieve high levels of environmental performance as we describe below. Such MNEs are more likely to face reputation effects and other sanctions if they fail to achieve higher levels of environmental performance. Such a global strategy is fundamentally different from (a) what can be thought of as a multidomestic (or polycentric in Perlmutter's, 1969, terms) strategy, that is, where firms develop "a multiplicity of identities to reflect each of the countries they operate in" (Kostova \& Zaheer, 1999, p. 73), or (b) an international (ethnocentric, according to Perlmutter, 1969) strategy where firms have "their identity is strongly rooted in the home country" (Kostova \& Zaheer, 1999, p. 73) and use foreign markets only to supplement their domestic sales (Bartlett \& Ghoshal, 1989). Polycentric or ethnocentric firms that are more focused on specific countries are also less likely to develop EMS that produce the highest levels of environmental performance.

Firms with a multidomestic strategy sometimes address environmental issues with a two-tiered approach of both a local and a global approach to regulation. This approach derives from the fact that countries individually develop regulations that govern the environmental performance of firms. Even the European Union (EU), which is slowly homogenizing regulations across its member states, allows EU member countries to develop or maintain individually stricter standards. This multiplicity of standards would seem to push firms toward more local strategies to address the different sets of rules. One might expect that the more decentralized the firm, the more decentralized the environmental strategy. However, firms increasingly see the competitive advantages of a consistently high-level 
approach to environmental performance, including proactive EMS and practices that exceed regulatory compliance (e.g., Aragôn-Correa \& Sharma, 2003; T. J. Dean \& Brown, 1995; Florida \& Davison, 2001; Hart, 1995; Klassen \& Whybark, 1999; Porter \& van der Linde, 1995). As firms expand their horizons into more host countries, developing a multiplicity of EMS to suit each set of local regulations may be economically prohibitive or simply more trouble than it is worth. In the short run, localized systems may reduce immediate compliance costs in low-regulation countries. However, developing and maintaining multiple systems to manage a diverse set of separately evolving policies could have long-term consequences in terms of costs and management challenges. Although firms will develop compliance-exceeding EMS only when the (not necessarily exclusively economic) benefits outweigh the costs, increasingly, firms are doing so.

Furthermore, with increasing numbers of countries adopting stricter emissions standards or even "take-back" programs for packaging and products (e.g., electronics, automobiles, and large appliances), worldwide environmental regulatory trajectories generally are upward "moving targets" (de Borchgrave, 1993; Gallarotti, 1995; Hoffman, 1997, 2001; Lewis \& Harvey, 2001; Porter \& van der Linde, 1995). An increasing regulatory trajectory makes keeping up with changes in, for example, 20,30, or 90 countries' environmental regulatory systems a daunting and expensive, if not impossible, task. Even though, as of this writing, the movement for regulations on global warming or greenhouse gases has stalled or overall U.S. standards seem to have leveled off or are even being softened, the evidence that worldwide trends in more operational environmental regulations are increasing is strong. As many countries debate or threaten to pull out of the Kyoto Protocol on global warming, areas as diverse as Bulgaria, Taiwan, and Ontario, Canada, continue to adopt stricter industrial emissions and product/packaging take-back requirements.

As regulations continue to increase, expectations on firms for improved performance will increase as well. Jack Stein, Director of Strategic Environmental Initiatives at Anheuser Busch, was quoted as saying the following about this point:

Environmental expectations are going to continue to evolve. To be successful, a company has to keep asking questions over and over about its environmental performance, and never become satisfied with the status quo. (Kreitz, 2002)

The development of the ISO 14000 and European Eco-Management and Audit Scheme (EMAS) series of environmental quality standards 
allows firms to develop country-independent EMS - something many firms have begun to do (Rondinelli \& Vastag, 1996). By adopting ISO 14000 or EMAS standards, firms attempt to position themselves to stay ahead of most countries' environmental regulation (e.g., Biondi, Frey, \& Iraldo, 2000; Miles, Munilla, \& McClurg, 1999). A strong motivation for firms to improve environmental performance proactively (via ISO 14000 or EMAS) is the potential to remove the firm's activities from the control of the direct regulation while providing operational autonomy in each country in which it operates (cf. Sharfman, Ellington, \& Meo, 1999). For a firm operating globally, ISO 14000 or EMAS certification provides an organized way for a firm to develop EMS that go beyond compliance in every host country in which it operates. Developing EMS to certified standards also provides the firm the ability to manage the various regulatory pressures it faces in a consistent way worldwide. Here are examples of the integrative use of the ISO 14000 standards from Motorola and Johnson \& Johnson:

Motorola sites around the world operate under a common EHS Management System (MS) framework. All Motorola manufacturing sites are registered to the globally recognized ISO 14001 environmental management system standard, through Lloyd's Register Quality Assurance (LRQA). (Motorola, 2003)

Operating Beyond Compliance with all applicable laws and regulations by uniformly meeting Johnson \& Johnson global environmental policies and standards, ISO 14001 environmental management system standards, and other voluntary principles to which we subscribe. (Johnson \& Johnson, 2001)

Rugman and Verbeke (1998a) refer to the development of ISO/EMAS certifiable EMS as creating "internationally transferable green capabilities" (p. 377). This "beyond-compliance" approach may enable the firm to develop green strategies that provide both cost-based and other competitive advantages as they enter additional foreign markets (Porter \& van der Linde, 1995; Rugman \& Verberke, 1998a, 1998b, 2002). When facing strong domestic and international environmental regulations, such a strategy may be particularly appropriate if it allows the firm to develop economies of scope both domestically and internationally (Rugman \& Verbeke, 1998b), entry barriers (Aragôn-Correa \& Sharma, 2003; T. J. Dean \& Brown, 1995), or first-mover advantages (Nehrt, 1998). Dowell, Hart, and Yeung (2000) suggest that there

appear to be forces that encourage MNEs (multi-national enterprises) to integrate and standardize their environmental practices globally. . . By in- 
vesting in state-of-the-art technology and processes ... MNE facilities may be able to achieve simultaneously world class costs, quality and environmental performance. In addition, MNEs may reap standardization benefits and other intangible advantages like positive reputation effects. (p. 1060)

In addition, the global context itself creates unique problems for the firm. The diversity of cultural, economic, regulatory, and social forces that firms face as they enter foreign markets creates a level of uncertainty and complexity quite different from one's domestic market (e.g., Bartlett \& Ghoshal, 1989; Prahalad \& Doz, 1987). When faced with such uncertainty and complexity, firms likely seek ways to reduce both stressors. One of the simplest ways to address the uncertainty and complexity is to limit the elements in the global context that cause them.

Environmental issues themselves are a great source of uncertainty and complexity (cf. Hoffman, 2001). When firms faced only legal environmental compliance, it was adequate to strive to meet the standards set by the U.S. Environmental Protection Agency and other regulatory bodies. Success in meeting such standards was easily determined. As a result of today's global pressures, more firms are heading toward systemic changes such as goals for the achievement of sustainability, fundamental changes to production processes to achieve a zero environmental footprint, working with customers and suppliers to ensure that their activities are environmentally benign, and so on. If the firm can remove such a large source of global uncertainty and complexity as the need to create and follow $n$ countries' environmental systems generates by shifting to a uniform approach that exceeds compliance everywhere, it will likely make the choice to do so (cf. Aragôn-Correa \& Sharma, 2003).

Furthermore, Kostova and Zaheer (1999) argue that global firms face serious challenges developing and maintaining legitimacy once they leave their home countries. Because legitimacy is essential for firms to operate, global firms must meet or exceed the legitimacy challenges they face (DiMaggio \& Powell, 1983). For example, global firms are "expected to do more than local companies in building their reputation and goodwill, ... [and] in protecting the environment" (Kostova \& Zaheer, 1999, p. 74) at minimum, as much as anything because they face a "liability of being large and visible" (p. 74). One effective set of legitimacy-seeking behaviors is for global firms to develop and maintain environmental performance that exceeds compliance wherever they operate. By doing so, there are fewer pressures when they face the difficulty of having to "manage their legitimacy through negotiations with their multiple environments (Kostova \& Zaheer, 1999, p. 71). 
Legitimacy and its myriad effects on the global firm are too multidimensional to address fully in our limited space (cf. Hoffman, 1999). However, as we look at the ways in which global firms address the idea, a theme emerges: legitimacy as the "license to operate" that is key to "long term survival" (Bansal \& Roth, 2000, p. 727). An example of how one global firm links its environmental management practice to legitimacy as license to operate is provided by David Francisco, Executive Vice President of Operations for Newmont Mining. He is quoted on the company's sustainability Web page linking the license to operate to the firm's daily activities:

Our ability to operate is dependent on our record in terms of safety, environmental stewardship, and our relations with communities. This is our social license to operate and it must be renewed every day. (Newmont, 2003)

There is, however, an alternative perspective on the linkage between a firm's level of globalization and environmental performance that would seem to contradict our previous arguments. This perspective, known as the pollution haven hypothesis suggests that multinational firms react to increasing regulatory and social pressures for environmental performance in one area by relocating to areas with less stringent regulations (Walter, 1982). The pollution haven hypothesis had received a great amount of attention but became particularly visible when Laurence Summers (then chief economist of the World Bank) in a leaked internal memo rather crassly suggested that

a given amount of health-impairing pollution should be done in the country with the lowest wages.... I think the economic logic behind dumping a load of toxic waste in the lowest-wage country is impeccable. (Economist, 1992)

However, despite the fact that this quote caused the hypothesis to receive even more extensive attention, it never received much empirical support (e.g., Christmann \& Taylor, in press; Ferrantino, 1997; Leonard, 1988). To this point, Mani and Wheeler (1998) argued,

Existing studies have reached mixed conclusions about the impact of development and environmental regulations on the international migration of pollution-intensive industries. Most studies focus on multinational investment and trade and find negligible displacement effects. However, two studies (Birdsall \& Wheeler, 1992; Lucas, Wheeler, \& Hettige, 1992) do find significant displacement of pollution intensive sectors to developing countries.... All of the existing studies share common weaknesses. They adopt simplifying assumptions such as constant sectoral pollution intensi- 
ties or abatement across countries. Few studies have looked beyond the dichotomy "developed-developing" in controlling the relative degree of regulation, and none has attempted to assess the separate effects of cross country regulation and input prices.... It seems reasonable to say that empirical findings are inconclusive because their scope and the supporting data have been quite limited. (pp. 217-218)

Rugman and Verbeke (1998a) echoed this point and suggested,

There is little empirical evidence supporting the pollution haven case. The empirical work of Grossman and Krueger (1993) on the activity levels in Mexico and the maquiladora areas along the U.S.-Mexico border demonstrates that U.S. MNEs have not shifted production activities there in order to avoid environmental regulations in the United States. Furthermore, other empirical evidence also fails to support the claim that international trade flows are affected by environmental regulations (Walter, 1982; Pearson, 1987; Leonard, 1988; Tobey, 1990). ... To summarize, our analysis of the pollution haven hypothesis reveals that environmental regulations at present appear to have little effect on the FSA-CSA [firm specific advantagescountry specific advantages] configuration and the location decisions of MNEs. (p. 371)

In fact, Eskeland and Harrison (1997) found that

our theoretical model indicates that the pollution haven hypothesis is unambiguous only in a very simplistic model of the multinational firm. ... In a variety of empirical tests, we have found almost no evidence of pollution havens. Instead, we find that foreign firms are less polluting than their peers in developing countries. (p. 28)

Even those studies where modest support for the hypothesis has been found suggest their own results may be equivocal. For example, the well known Low and Yeats (1992) study found developing countries were growing comparative advantages in dirty industries at rates appreciably faster than developed nations. However, these authors also added that

there is no shortage of competing explanations for dirty industry dispersion ... the idea that trade flows reflected natural resource endowments appears a little more persuasive ... the evidence of dirty industry dispersion examined in this paper is unlikely to be adequately explained by environmental policy. (p. 103)

Key reasons that the hypothesis may not predict the ways in which firms will behave include liability and reputation concerns (Lucas et al., 1992; Dasgupta, Laplante, \& Mamingi, 1998) or the effects of political instability. For example, in 2003, Rio Tinto and British Petroleum PLC 
sold their entire joint stake in the Indonesia's second largest coal producer to a local company because of the political risks of doing business in this arguably poorly environmentally regulated country (Aglionby, 2003).

In a comprehensive report, the International Institute for Sustainable Development (IISD) summarized several more explanations why the pollution haven hypothesis has not been supported empirically. They argued,

The costs of environmental compliance are so low relative to other considerations (such as labour costs, political risk, and proximity to resources) that even if great differences in regulatory stringency existed between jurisdictions, they would not be enough to prompt a move.... Differences in the stringency of regulations between one jurisdiction and another are not great enough in most cases to stimulate migration. ... Firms are increasingly cautious about what standards they follow in overseas operations, knowing that future regulations in those areas may demand costly retrofits, and mindful of the opinion of consumer at home. (IISD, 2001, p. 8)

We should note, however, that regardless of the lack of evidence to support the hypothesis in the aggregate, anecdotal evidence of reprehensible firm environmental behavior exists in locales where regulations allow it, and such evidence may not be captured by the research we cite above. The lack of supporting analyses of the pollution haven hypothesis does "not account for the behavior of individual firms" (Low \& Yeats, 1982, p. 103) or for the behavior of firms with solely domestic operations.

Despite the fact that the pollution haven hypothesis has not been supported empirically, Letchumanon and Kodama (2000) point out that "practitioners such as policy makers, politicians and the business community are absolutely convinced of such impacts" (p. 61). The idea that firm levels of globalization would be a positive force in environmental performance is untenable to many in the environmental community. The stereotype of the avaricious multinational eschewing environmental regulation at every turn resonates with many academics and activists. Certainly, there are numerous examples of firms seemingly or actually engaging in reprehensible environmental performance- even firms for whom high-level environmental performance is a stated goal (e.g., The Body Shop, Royal Dutch Shell, etc.). We propose, however, that the days where multinationals might even attempt to find pollution havens are numbered. The forces we discuss in our model are becoming increasingly powerful at what appears to be an increasing rate (IISD, 2001). As such, the logical choice for more globalized firms becomes environmental performance that exceeds compliance everywhere the firm does business rather than opportunistically engaging in poor performance simply because it is possible. 
In addition to regulatory pressures, firms face increasing amounts of social pressure to be better environmental citizens that may not manifest in the form of regulations. Reilly (1990) argues that "once the present seems relatively secure, people can focus on the future" (p. 16). In increasingly greater numbers, citizens of developed and developing nations have begun to view the present as relatively secure so they are beginning to worry about the future. Individuals put this concern into action by (among other things) pressuring corporations to be better environmental citizens. Although the belief that the present is relatively secure is certainly not universally shared among all citizens of all nations, the view is shared by a sufficient number of people to create pressures for change among corporations. Therefore, as the "need for green" has become an increasingly important force in developed and developing societies, firms face increasing demands from customers and other stakeholders to adopt increasingly higher standards of environmental performance (Andrews, 1998; Hoffman, 2001; Sharfman, Ellington, \& Meo, 1997), which requires behavior beyond compliance and taking steps toward sustainability.

Several writers have provided evidence that societal evaluation of firm performance concerning this need for green manifests itself through firm valuation via the stock market. Several studies have found evidence that positive and negative environmental events for firms had corresponding effects on the level of stock market returns of the studied firms (Feldman, Soyka, \& Ameer, 1996; Hamilton, 1995; Klassen \& McLaughlin, 1996). These findings suggest that society, through stock markets, rewards firms that exhibit high levels of environmental performance and similarly punishes firms that perform poorly. Similarly, using accounting data instead of market returns, Hart and Ahuja (1996) and Russo and Fouts (1997) demonstrated a positive relationship between environmental and firm financial performance. Finally, Dowell et al.'s (2000) results support the idea that "firms adopting a single, stringent global environmental standard have much higher market values" (p. 1059).

An additional factor that can induce the firm to go beyond compliance is the growing recognition that pollution is economic waste-regardless of where it is generated. By this reasoning, any dollar's worth of material going up a smokestack, down a sewer pipe, or into a trashcan is a dollar not going into the pockets of stockholders. However, understanding this calculus is the easy part. Several writers (e.g., Shaft, Ellington, Meo, \& Sharfman, 1997; Steger, 1996) have argued that firms face a fundamental challenge in implementing the changes necessary to address this calculus. Historically, a cost-minimization approach and a local strategy focusing on compliance were sufficient. However, the growing societal demands for meaningful improvement in environmental performance (i.e., 
improvement in the firm's ability to manage or limit its environmental "footprint") require a revolution in environmental management practice past command and control, "end-of-pipe" compliance technology, or even pollution-prevention methods toward sustainable practices like the life-cycle approaches we describe next.

To implement the changes fully that the approach to sustainability requires, firms are under increasing pressure to manage their environmental footprint beyond their own boundaries to include the entire physical system life-cycle of their products or services. This entails an examination from the creation of inputs to the final disposal, decontamination, recycling, or reuse of outputs. In this approach, the firm improves environmental performance by eliminating waste and emissions before they occur as well as by identifying more environmentally benign methods and materials. The institutional pressures or incentives for firms to adopt a more LCOEM approach come from such disparate sources as the Dutch regulations concerning Life-Cycle Analysis, U.S. government regulations on CFC labeling of supplied products, EU product and packaging take-back initiatives such as the German Duales System Deutschland and the Swedish Kretslopp programs, and the provisions of ISO 14041— the life-cycle analysis portion of the international standards for environmental quality. Furthermore, leading-edge firms are raising the standard for others in their industries by using life-cycle approaches for competitive advantage (e.g., Baxter Healthcare, AT\&T, DuPont, Interface, etc.). In addition, more and more professional business organizations (e.g., World Business Council for Sustainable Development, Business for Social Responsibility, OECD) exert normative pressure on firms to adopt more life-cycle-oriented approaches. When a firm adopts LCOEM, it addresses environmental management concerns up and down the physical system life cycle of its products and services.

LCOEM more fully allows a firm to improve environmental performance by addressing environmental impacts both upstream and downstream from its own efforts by integrating the environmental activities of suppliers and the environmental needs of customers as a part of a firm's overall environmental management practice. In a world of increasingly global supply and customer chains, the need for more LCOEM approaches necessitates the homogenization of the focal firm's EMS toward higher levels of environmental performance beyond compliance.

In summary, our argument suggests three sets of forces that influence firms to adopt global strategies for their corporate environmental performance. First, the multiplicity of regulatory trajectories that MNEs face in the increasingly complex global context provides economic, competitive, and managerial incentives for them to develop EMS to exceed 
compliance. Second, societal or institutional pressures and green movements throughout the world directly influence firms to improve their environmental performance regardless of where they operate. Finally, there is a global constellation of additional institutional forces pushing firms toward LCOEM as the organizing model for corporate environmental performance. LCOEM approaches entail high-level environmental performance of both focal firms and their suppliers and customers - again country independent. In the next section, we present a propositional model (based on globalization and institutional theories) of the antecedents of high-level environmental performance.

\section{THEORETICAL MODEL}

We assert that the higher the level of environmental performance, the more likely the firm routinely goes beyond regulatory compliance minimums. Although it would appear to be more precise to organize the theory around a beyond-compliance construct, such a concept is relativistic and country-contingent, so it does not provide the basis for strong theory. The "high levels of environmental performance" construct is conceptually clearer, more widely accepted in the literature, and more amenable to future operationalization. As our definition of high-level environmental performance, we adopt the Aragôn-Correa and Sharma (2003) approach, which is consistent with going beyond compliance and suggests that such behavior entails

proactive postures [which] involve anticipating future regulations and social trends and designing or altering operations, processes, and products to prevent [rather than merely ameliorate] negative environmental impacts. (p. 74)

Before we present the arguments regarding the globalization and institutionalization pressures firms face, however, we must introduce a theoretical control construct-the firm's level of organizational slack (e.g., Cyert \& March, 1963; Sharfman, Wolf, Chase, \& Tansik, 1988). There is a growing body of literature to suggest that firms' choices in environmental performance are economically driven in a way other than one might normally suppose. Although environmental decisions must make sense economically, a literature has developed that suggests that only firms that can afford higher levels of environmental performance make such choices. Sharma (2000) showed that the environmental management choices that managers make are dictated in part by the level of discretionary resources (slack) present in organizations. Without sufficient 
discretionary resources, managers have little choice but to minimize the costs of environmental performance-even when there are obvious benefits to exceed the minimum. Because global firms are generally larger, they are more likely to have such slack resources-furthermore, as Kostova and Zaheer (1999) argue, global firms also will face concomitantly greater pressures on their legitimacy (e.g., expectations about environmental performance), so they are more likely to use such slack resources to improve environmentally. As such, we predicate our model on the assumption that managers in global firms have sufficient slack resources present in their organizations to allow global strategies for environmental management choices beyond compliance.

\section{Globalization Constructs}

We selected the globalization constructs to include in our model by using three criteria. First, based on a review of the literature, we selected those constructs that represent the major portions of globalization theory. Second, we identified constructs most consistent with our observations regarding the adoption of global strategies toward corporate environmental performance. Finally, as global strategies are based on both the choices of management and the context within which the firm operates (cf. Dean, Sharfman, \& Ford, 1991), we selected constructs to represent both elements. The globalization constructs we include are level of globalization and global and industry diversification. Our contextual variables represent the internal and external contexts of the firm-namely, organizational centralization, formalization, and industry or competitive pressures for global integration and local responsiveness.

Level of globalization. Grant (1995) in his assessment of Levitt's (1983) globalization theory suggests that "Levitt's thesis is not that customers are the same the world over. National and regional differences exist and cannot be ignored. But underlying these differences is a commonality of goals" (p. 229). As we argued above, improved environmental performance is an increasingly common goal across cultures-particularly those cultures that belong to regional trade blocks such as the North American Free Trade Area (NAFTA), the EU, and the Association of South East Asian Nations (ASEAN) (cf. Eliste, 2002). The more a firm competes globally, the more it is exposed to multiple demands on its environmental performance. Although a firm competing solely in the EU or ASEAN blocks would face less variety than a firm that is more broadly diversified globally (cf. Kostova \& Zaheer, 1999), even the EU-focused firm would face broader institutional pressures than a domestic-focused 
company. At the most basic level, this globalization increases the likelihood of firms' developing a high-level global approach to environmental performance. Although the adoption of a global strategy is not sufficient as a cause of high-level environmental performance in an MNE, we suggest it is necessary. This argument is also consistent with Khanna and Anton (2001), who found that "firms with a stronger multinational presence are more likely to adopt a comprehensive EMS" (p. 23), as well as Christmann and Taylor (in press), who suggest that "globalization increases institutional and customer pressures on firms to surpass local requirements even when tempted by lax regulations and enforcement" ( $p$. 23). Kostova and Zaheer (1999) argue that the "greater the number and variety of counties in which a [global] firm operates, the greater the challenge [in] . . maintaining legitimacy" (p. 71). Meyer and Scott (1983) suggest that an organization's legitimacy is "negatively affected by the number of different authorities sovereign over it" (p. 202). Given the worldwide, rising expectations concerning environmental performance, firms that exceed local compliance requirements are likely to have fewer problems maintaining their legitimacy. BASF puts it simply,

Implementing Sustainable Development is especially challenging for a transnational company: BASF operates in more than 170 countries ... we need to develop strategies and tools that can be applied worldwide. (BASF, 2003)

Imperial Chemical Industries (ICI) puts forth a similar position:

Laws and regulations vary around the world reflecting regional and local preoccupations and concerns. As a global company with a presence in more than 55 countries, we believe that we should operate according to global standards. (ICI, 2003)

This leads to our first proposition:

Proposition 1: The greater the degree of the firm's globalization, the higher the level of the firm's environmental performance.

Global and industry diversification. Although overall globalization leads to increased environmental performance, we suggest that variation in the types and locations of business conducted across the globe have an effect as well. Firms that are narrowly focused in one or two industries may be more successful at creating limited EMS because of their ability to develop multidomestic, country-specific strategies. With fewer industries to manage, it is more possible for a firm to tailor EMS to the countries for 
each industry. Similarly, if a firm operates in only a few countries, it is more able to create specific EMS for those countries. However, firms that are more widely diversified across industries or across a wider range of countries face more difficulty in responding to the multiplicity of demands they face. As compliance becomes more complicated, firms are increasingly likely to find ways to relieve their compliance burden via integrative and comprehensive EMS. The more varied contexts a global firms faces, the more legitimacy problems it may encounter, and the legitimacy problems in one environment may spill over to the other segments of the global firm (Kostova \& Zaheer, 1999). Going beyond compliance everywhere it operates allows the global firm to limit legitimacy threats from the environmental sector. Broadly diversified firms are more likely to develop EMS to manage the environmental performance that will help them stay ahead of the regulatory trajectories they face across industries and countries. It is hard to imagine that a firm would create a unitary system to meet the lowest standards it faces.

Volvo provides an instructive example of the effect of diversification:

The Volvo Group includes many types of production facilities in many markets, covering a wide range of production processes. The variation in environmental performance is substantial due to differences in technical standards, legal requirements and environmental awareness. The environmental requirements represent a first attempt to define minimum levels of selected parameters with a view to promoting more harmonized performance. One example of its use is to establish minimum environmental performance in [newly] acquired production facilities, regardless of production volume. The basic principle is that Volvo operations shall comply with the relevant legal requirements or with the environmental requirements for Volvo Group Production, whichever are more stringent. (Volvo, 2003)

This argument leads onto our next two propositions.

Proposition 2: The more diversified the firm is across industries, the higher the level of the firm's environmental performance.

Proposition 3: The more diversified the firm is across countries, the higher the level of the firm's environmental performance.

Dooley and Fryxell (1999) investigated the effects of different types of diversification on environmental performance in domestic firms. Their results suggest that our propositions are most likely to hold for firms with related diversification strategies as opposed to firms with unrelated (conglomerate) diversification approaches. The more unrelated the diversification, the more difficult it is to implement a unified approach to environmental management. 
Strategic choices like we describe above do not take place independent of the firm's context. Ghoshal and Nohria (1993) investigated the relationship between three organizational dimensions and the globalized firm's fit with the business environments in which it operated. Two of these dimensions have proliferated in the organization literature: formalization and centralization (e.g., Pugh, Hickson, Hinings, \& Turner, 1968). Ghoshal and Nohria use normative integration (Van Maanen \& Schein, 1979) as a third dimension. We consider these three dimensions as explanatory constructs regarding globalized-firm environmental performance.

Formalization. The key element in formalization is the extent to which firms create extensive written policies to govern their day-to-day operations (cf. Pugh et al., 1968). Ghoshal and Nohria (1993) suggest that globalized firms that develop more formalized policies and procedures implement said procedures across all their subsidiaries. Such standardization makes implementation more consistent but also limits local discretion. Because formalized bureaucratic systems to govern environmental performance limit local discretion, globalized firms must develop these systems to meet or exceed any local standard the firm encounters, or face the consequence of violating local regulations. For example, the formalization of EHS systems through the adoption of the chemical industry's Responsible Care program led to major EHS-management improvements particularly at larger firms (Kappas, 2000). By formalizing standards, the firm will likely push the overall firm level of environmental performance up. This argument leads to our next proposition:

Proposition 5: The more formalized a firm, the higher the firm's level of environmental performance.

Centralization. Centralization places power and control of the firm and its resources in the hands of top management. In the case of the globalized firm, this usually means the corporate headquarters. Centralization also limits or removes local autonomy. When firms are centralized, they put in place control systems to support that centralization. By curtailing local autonomy, firms also take away their subsidiaries' options in responding to environmental regulation. However, when the firm centralizes, it must ensure that it at least meets all local requirements. Because compliance is the minimum for most firms and requirements vary broadly across countries, firms with centralized systems will be forced to develop EMS that allow them to stay ahead of compliance wherever they operate (see the examples from Bristol-Myers Squibb, General Motors, Johnson \& 
Johnson, and Motorola we mention above). This argument leads to our next proposition:

Proposition 6: The more centralized a firm, the higher the firm's level of environmental performance.

Normative integration. Normative integration occurs when employees are socialized "into a set of goals, values and beliefs that then shape their perspectives and behavior" (Ghoshal \& Nohria, 1993). Building on Van Maanen and Schein (1979), we suggest that organizational culture is both formed by the process of normative integration and in turn stimulates this integration. As the firm becomes more normatively integrated, control in the firm becomes dominated by the organization's dominant values and beliefs, that is, its culture. Although the control that shared values and beliefs exert is informal (Ouchi, 1980), it still homogenizes behavior throughout a firm. All firms must, at least, meet compliance requirements, and localities vary in their regulations. When a firm is normatively integrated, it will be compelled to develop a unified approach to address environmental performance. To insure compliance, in firms with strong levels of normative integration, the corporate values and beliefs behind the EMS will push the firm toward environmental performance that exceeds compliance in most localities-just to make sure the minimums are met in all localities. Here is an example of how Dow Chemical pursues normative integration of its perspective toward sustainable development throughout the company:

Doing good for the environment is not just driven by moral considerations. It simply makes good business sense as well. The ability to integrate the principles of Sustainable Development might very well become a determining factor in the long-term survival of companies. ... In 2002, we made significant progress in integrating the 12-Point Sustainable Development Operating Plan with the various businesses, functional, and site strategies within the company. Within Dow, the major mechanism for delineating strategy and implementation is called the Managing Improvement, or MI, Plan. Over a dozen businesses have completed a mapping of the 12-Point Plan with their MI Plan, looking for gaps and areas of strength. This then leads to action items for the individual businesses. The focus for 2003 will be on a broader education tool for Dow employees. We are working with the World Business Council on Sustainable Development to develop and use an on-line training tool designed for use by all employees and intended to provide personal relevance to all employees. This effort is scheduled to be piloted in the first half of 2003, with rollout in the second half. (Dow, 2002)

Such normative integration is even more likely when firms have high levels of individual concern for environmental issues among their employees 
or from top management, although resistance from specific facilities or countries might impede the integration process (Bansal \& Roth, 2000). This argument leads to our next proposition:

Proposition 7: The more normatively integrated the firm, the higher the firm's level of environmental performance.

Pressure for global integration and local responsiveness. Although the organization's characteristics should be strong drivers of environmental performance, we anticipate that the external context within which the firm finds itself also has major effects. In particular, industries themselves push firms toward global integration or local responsiveness. In commodity industries (coal, steel, cotton), products are not particularly differentiable, there is little or no need for products to be locally responsive, and there are considerable economic incentives for global integration. Alternatively, in consumer industries (food, clothing, cosmetics), although some products can succeed everywhere around the world (Levi's, McDonalds, Coca-Cola), increasingly, consumers want products tailored to their needs and wants. When firms operate more in industries where global integration is the dominant force, they are more likely to develop global high-performing EMS that allow them to insure that compliance is exceeded everywhere they operate. Coca-Cola provides us an interesting example of how global integration leads to the development of integrated environmental systems. In a speech to the 2002 Global Environmental Management Initiative's annual meeting, Carl Ware, Vice President for Public Affairs and Administration at Coca-Cola, indicated the following:

For a company that does business in more than 200 countries, each with its own set of labor and environmental laws, this can be an exceedingly frustrating and challenging experience.... [It] forces a company's management to agree on a set of core principles for which the company stands and by which it will abide that is good for the global community, for the company and for its shareholders. (Steele, 2002)

This argument leads to our next proposition:

Proposition 8: When firms operate in predominately globally integrated industries, they will exhibit higher overall levels of environmental performance.

When firms tailor their strategies to the needs of local environments, they likely will tailor their EMS to the countries in which they operate. Locally tailored systems will tend to produce environmental performance that follows a different pattern. By focusing on local rather than global 
standards, firms are more likely to focus on compliance (as a maximum) everywhere they operate. As such, they will experience wider variance across countries, particularly if they operate in both higher and lower regulation environments. For example, locally focused firms with operations ranging from Bangladesh (a lower regulation environment) to the Netherlands (one of the highest regulation environments) will exhibit enormous variety in their levels of environmental performance across their operations. In addition to wider variance in performance, firms that focus solely on local regulation likely will exhibit a lower average level of environmental performance (by country) than the firm that adopts a global perspective. This argument leads to our next proposition:

Proposition 9: When firms operate in industries where local responsiveness predominates, they will exhibit lower average levels of environmental performance per country.

\section{Institutional Constructs}

Whereas the globalization constructs we describe above address the strategic pressures placed on firms, there are forces in the firm's institutional context that push them toward global EMS strategies. MNE environmental performance is shaped by the institutional context within which firms find themselves. In their institutional arguments, DiMaggio and Powell (1983) suggest that there are three sets of forces that push firms toward similarity or isomorphism: coercive, mimetic, and normative. Sharfman et al. (1997) argue that there are elements of each of these forces in the global institutional environment that act as prime drivers pushing firms toward improved environmental performance (cf. Deephouse, 1996; Haveman, 1993). In this section, we describe the specific elements of the institutional forces in our model.

Coercive pressures and regulation. Coercive pressures in environmental management come mainly from regulation. Because the regulatory trajectories in most countries are a moving target, typically upward, firms have to develop a rational way to address the changes. Increasingly, firms address these frequent changes in the institutional environment by developing EMS that remove them from regulation (e.g., Sharfman et al., 1999). Even if firms cannot remove themselves from regulation, the presence of extensive regulatory structures in several countries pushes firms toward EMS that put them ahead of the regulations as much as possible. To this point, de Borchgrave (1993) argued, 
Adopting a proactive and far-reaching environmental strategy allows organizations to anticipate rather than submit to emerging regulatory constraints and to profit from the opportunities environmental trends present in terms of competitive positioning. (p. 48)

Conoco used its desire to maintain operating autonomy and environmental innovation to both improve its environmental performance and remove itself from regulatory strictures:

With its threat of MACT (maximum available control technology), the CAAA (Clean Air Act Amendments) stood to severely constrain Conoco's activities. . . . Conoco values its operating autonomy even more than most firms. Given this likely restraint of the firm's discretion, Conoco used innovation to avoid the pressure of this regulation at the CCU sites while maintaining its operating autonomy. (Sharfman et al., 1999, pp. 105-106)

This leads to our next proposition:

Proposition 10: The higher the average level of regulation that a firm faces across the countries in which it does business, the higher the firm's level of environmental performance.

Mimetic pressure and strategic isomorphism. Firms also face general mimetic pressures from market leaders (DiMaggio \& Powell, 1983). In regard to environmental performance, as American firms venture further abroad in their activities, they face firms (mainly from Europe, such as ABB, Statoil, Volvo) for whom environmental performance is a competitive advantage (e.g., Kärrberg, personal communication, August 8, 1997). These firms engage in activities so far beyond compliance that they raise the bar environmentally for everyone competing in their industry or country combinations (e.g., Shaft, Sharfman, \& Swahn, 2002). When the mimetic pressure toward isomorphism is targeted on environmental performance, the dynamic will be different. In such cases, leading firms are likely to concentrate on behaviors that will provide them with competitive advantage. By doing so, the leading firms will move the overall level of environmental performance in their industries up, not down. This dynamic is especially likely in industries with a great deal of cohesion (Bansal \& Roth, 2000), that is, strong interconnections between and among actors. In the following quote, we see how Johnson \& Johnson attempts to exert mimetic pressures:

Compliance with regulatory requirements is a starting point, but as a corporate leader we must do more by encouraging ... global standards for perfor- 
mance. ... We are implementing global ... standards that go beyond local country regulations. (Johnson \& Johnson, 2001)

This leads to our next proposition:

Proposition 11: The higher the level of mimetic environmental isomorphic pressures it faces, the higher the firm's level of environmental performance.

External normative pressures. As we argue above, all firms face increasing external normative pressures for improved environmental performance from specific societies, activists, and nongovernmental organizations. The normative elements of the business environment pose particular difficulties for global firms as they work to maintain legitimacy (Kostova \& Zaheer, 1999). Normative elements come from the value structure of a society, are more tacit, and hence are more difficult for an outsider to learn. The external normative pressures firms face to improve their environmental performance are manifest in many ways. Some of the pressure comes from the media, some comes from nongovernmental organizations, and others come from shareholders. Although firms will vary in the responses to these types of institutional pressures (Oliver, 1991), the general trend seems to be that when firms face high levels of external normative pressure for environmental performance, they tend to increase the level of their environmental performance. In the following text, Dow Chemical describes how the license to operate concept comes from society and is part of the values underlying its entire approach to sustainable development:

The world is rapidly changing. Scarcity of resources, continuing population growth and the influence of human activity on the future of the world are causes for concern. Society, which ultimately holds our license to operate and grow, expects industry to play its part in the resolution of these issues. In return, companies that take on this challenge can look forward to a better relationship with community neighbors, a boost in employee motivation, increased customer loyalty, reduced costs and liabilities and a better corporate reputation. All of which have a direct or indirect influence on a company's financial results. (Dow, 2002)

This argument leads to our last proposition:

Proposition 12: The higher the level of external normative pressures toward improved environmental performance it faces, the higher the firm's level of environmental performance. 


\section{DISCUSSION}

In this article, we present a propositional model that links institutional and globalization theory together as a theoretical answer to the following question: Why do multinational firms exceed compliance? Whereas neoclassical economic theory might suggest that behavior exceeding compliance is irrational-at least in the short term-we see examples of such behavior every day. However, previously, we have had only limited theoretical explanations as to why such behavior occurs (e.g., Aragôn-Correa \& Sharma, 2003; Bansal \& Roth, 2000). In this article, we propose that as firms increase in their levels of globalization (i.e., adopt more of a truly global or geocentric strategy), they face increasing strategic and institutional pressures that cause them to rationalize their environmental efforts upward. Such firms are the ones most likely to exceed compliance wherever they operate. Rather than devolving their activities to the lowest common denominator as the pollution haven hypothesis might suggest, under the conditions that we specify, firms will rationalize up. For example, as regulatory trajectories coalesce upward among countries, firms lose discretion in their activities and increase their costs if they must manage multiple environmental management schemas. As societies around the world ratchet up the level of environmental performance that they expect from firms, it is easier for an MNE to rationalize its EMS upward. As industryleading firms define environmental performance as a source of competitive advantage, follower firms feel pressure to adopt such practices.

The key implication from our model is that environmental performance for globalized firms is becoming a response to global pressures rather than to specific local regulations. Whereas firms that are heavily globalized are likely to behave as our propositions suggest, it is likely through isomorphic pressures that smaller firms will follow suit. These firms may not necessarily have adopted a greener attitude but may change their behavior simply because of the pressures that more proactive global firms (e.g., ABB, AT\&T, DuPont, etc.) exert throughout their industries and throughout the world. The specific effects of mimetic, isomorphic, and other institutional forces would be very fruitful future research areas.

We recognize that the model may be perceived as anywhere from counterintuitive to heretical by members of the environmental community. Each time the World Trade Organization and other proponents of globalization meet, the streets surrounding the site become a battleground in no small measure because of the perception of what globalization has done to the environment around the world. In this article, we propose a 
theory that suggests the opposite. Few will argue that multinationals have not, in the past, wreaked havoc on ecologies around the globe-in both home and host countries. However, as the cliché suggests, "That was then-this is now." The multinationals of the past could be seen as international (ethnocentric) in their strategy, that is, attempting to extend their domestic markets by simply selling their existing products abroad (e.g., Bartlett \& Ghoshal, 1989) and exploiting their foreign environment at the same time. However, recent literature in international business suggests that such a strategy was largely unsuccessful and is rarely followed by MNEs today (e.g., Hill, 2003). This was seen as the cheapest approach, and there were few pressures to behave otherwise. As we argued above, consistent with Reilly (1990), global firms in the 21 st century face a world of increasing regulation, increasing social attention, and increasing market pressures concerning their performance in general—not just their environmental performance. They face the need to balance globalization with local responsiveness, but the pressures for the adoption of global strategies, particularly in terms of environmental performance, seem to be winning. The idea of a pollution haven - where the multinational would stash dirty processes, products, or wastes-is increasingly a thing of the past. Today's multinational faces incredible scrutiny from governments, nongovernmental organizations, communities, and other stakeholders particularly because of the pervasiveness of the Internet. Although leading firms (e.g., Nike) face more pressure than do lower tier companies (e.g., Reebok), all MNEs face increased scrutiny. Furthermore, normative institutional pressures (e.g., the Global Reporting Initiative) to make corporate activity more transparent increase this scrutiny even further. This scrutiny has increased the cost of pollution for many reasons, including the increased risk of discovery, reputation effects, and increased threats of lawsuits. The increase in the potential costs of pollution has reached a point that the logical action for the global firm is to rationalize environmental systems to stay ahead of the regulations and other pressures firms face. Being reactive is expensive while being proactive can limit the costs and hassles of compliance (Porter \& van der Linde, 1995; Sharfman et. al, 1999 ) as well as the transactions costs involved in a global strategy. We do not propose that when global firms rationalize their environmental systems toward the highest common denominator, they are doing so necessarily out of any sense of moral or ethical imperative. Although that may be the case for some individual firms, the model we propose in this article is predicated on the idea that good performance by a global firm in today's context entails high levels of green performance (cf. Allenby, 2000).

One might question whether firms that appear to exceed compliance engage in so-called greenwashing (dressing up their activities in an 
environmental patina) or whether their performance is truly well above standards. However, the dawn of the Internet age has put firms under scrutiny like never before. As a result, greenwashing put in the place of real environmental performance is more likely to be detected. In the speech we cite above, Carl Ware of Coca-Cola also described the effect that this scrutiny has on his firm. Steele Communications (2002) described him as saying,

People seem to expect more from his company than they do of many others, likely due to the worldwide visibility of the Coca-Cola brand and the sheer size and reach of the organization [and that] . . . the Internet has enabled groups to clothe the sheerest nonsense in the garb of respectability and send it twice around the world with the click of a mouse ... [so] acting with integrity has always been a competitive advantage and is even more so in today's wired world.

The answer to the questions concerning greenwashing ultimately is an empirical one, and there are several other interesting future research issues here as well. Do the pressures we describe above inhibit or facilitate greenwashing? As firms face more pressures for improved environment, it may create an incentive to make their performance look as green as possible while doing as little as possible. As such, there would be a concomitant incentive to greenwash rather than to fundamentally change systems. In this circumstance, there is asymmetric information between the firm and any observers. The firm knows exactly what it is doing. Observers can go only by what they can see. Alternatively, however, several recent, highpublicity problems faced by supposedly environmentally proactive firms (e.g., The Body Shop) would suggest that between governments, activists, nongovernmental organizations, and societies, there are sufficient monitoring capabilities to catch greenwashing and sufficient penalties (including reputation effects) if firms engage in such practices. Furthermore, do the pressures affect greenwashing more in consumer-oriented firms than industrial marketers? Consumer-oriented firms generate more public visibility and may have more incentive to behave better. However, industrial marketers often engage in dirtier processes that generate concerns with governments and activist groups, thus creating a different type of visibility. The question becomes who faces more pressure to perform better?

A related question about the effects of these forces concerns whether manufacturing or marketing operations face greater pressure. Traditionally, firms face the greatest environmental pressure when they engage in manufacturing, with less pressure occurring when firms engage in only in-country marketing and sales activities. The new regulatory challenges 
that marketing organizations face come from a broad increase in product and packaging take-back requirements. As product and packaging takeback requirements increase, firms without in-country manufacturing operations face more extensive challenges to address the new regulations. If a firm has an in-country manufacturing plant, then it can integrate product and packaging take-back into manufacturing far more easily. If a firm does not have in-country manufacturing and faces take-back regulations, then it has to set up a separate system, participate in a collective system (if such a thing exists), or outsource for take-back. Although the scrutiny that take-back generates may pale next to the pressures of manufacturing or extraction, the distinction concerning regulatory intensity between where the firm operates and where it manufacturers is less than it used to be and deserves further examination. Alternatively, perhaps the question is not manufacturing versus sales or marketing but again concerns consumer versus industrial marketers. Do consumer marketers face greater scrutiny regardless of whether they manufacture in country? Future research will also help answer all these questions.

\section{CONCLUSION}

In this article, we develop a model to clarify why firms engage in levels of environmental performance that routinely exceeds compliance. Starik and Rands (1995) suggest a multilevel approach to understanding how and why firms head toward sustainable practice. We choose the institutional level upon which to focus our theory, consistent with the approach of authors such as Jennings and Zandbergen (1995) or Hoffman (1999). Rather than examining the internal workings of the firm, the values of its managers, or the economics of green behavior, we present a macrolevel theory of firm environmental performance. We posit that firms respond in terms of environmental performance to the context within which they find themselves. Today, firms adopting a global strategy find themselves in a context where the most appropriate and effective choice is to rationalize their environmental performance to a standard that places them ahead of compliance and social pressures.

\section{REFERENCES}

Aglionby, J. (2003, July 22). Indonesia challenge to final BP mine sale. Guardian Unlimited. Retrieved October 1, 2003, from http://www.guardian.co.uk/indonesia/Story/ 0,2763,1003157,00.html. 
Allenby, B. R. (2000). The fallacy of "green technology." American Behavioral Scientist, 44(2), 213-228.

Andrews, C. (1998). Environmental business strategy: Corporate leaders' perceptions. Society and Natural Resources, 11, 531-540.

Aragôn-Correa, J. A., \& Sharma, S. (2003). A contingent resource-based view of proactive corporate environmental strategy. Academy of Management Review, 28(1), 71-88.

Bansal, P., \& Roth, K. (2000). Why companies go green: A model of ecological responsiveness. Academy of Management Journal, 43(4), 717-736.

Bartlett, C. A., \& Ghoshal, S. (1989). Managing across borders: The transnational solution. Boston: Harvard Business School Press.

BASF. (2003). Values and principles for BASF. Retrieved September 20, 2003, from http:// www.basf.de/en/corporate/sustainability/.

Biondi, V., Frey, M., \& Iraldo, F. (2000). Environmental management systems and SMEs. Greener Management International, 29, 55-70.

Birdsall, N., \& Wheeler, D. (1992). Trade policy and industrial pollution in Latin America: Where are the pollution havens? In Patrick Low (Ed.), International trade and the environment. Washington, DC: World Bank.

Bristol-Myers Squibb. (2003). 2002 sustainability report. Retrieved August 11, 2003, from http://www.bristolmyers.com/static/ehs/vision/data/vision.html.

Christmann, P., \& Taylor, G. (in press). Globalization and the environment. Journal of International Business Studies.

Cyert, R., \& March, J. (1963). A behavioral theory of the firm. Englewood Cliffs, NJ: Prentice-Hall.

Dasgupta, S., Laplante, B., \& Mamingi, N. (1998). Capital market responses to environmental performance in developing countries. Boston: World Bank, Development Research Group.

Dean, J. W., Jr., Sharfman, M. P., \& Ford, C. A. (1991). Strategic decision making: A multiplecontext framework. In J. Meindl, R. Cardy, \& W. Puffer (Eds.), Advances in information processing in organizations (Vol. 4, pp. 77-110). Greenwich, CT: JAI Press.

Dean, T. J., \& Brown, R. L. (1995). Pollution regulation as a barrier to new firm entry: Initial evidence and implications for future research. Academy of Management Journal, 38, 288-303.

de Borchgrave, R. (1993). It's not easy being green: Developing an EC environmental strategy. The Journal of European Business, 4(3), 48-53.

Deephouse, D. L. (1996). Does isomorphism legitimate? Academy of Management Journal, 39, 1024-1039.

DiMaggio, P. J., \& Powell, W. W. (1983). The iron cage revisited: Institutional isomorphism and collective rationality in organizational fields. American Sociological Review, 48, 147-160.

Dooley, R. S., \& Fryxell, G. E. (1999). Are conglomerates less environmentally responsible? An empirical examination of diversification strategy and subsidiary pollution in the U.S. chemical industry. Journal of Business Ethics, 21(1), 1-14.

Dow. (2002). Dow Chemical Corporation 2002 sustainability report. Retrieved September 19, 2003, from http://www.dow.com/publicreport/2002/stewardship/case.htm.

Dowell, G., Hart, S. L., \& Yeung, B. (2000). Do corporate global environmental standards create or destroy market value? Management Science, 48(8), 1059-1074.

Economist. (1992, February 8). Let them eat pollution. Economist, 322(7745), 66.

Eliste, P. (2002). Three empirical essays on environmental regulations, strategic interaction, and regional trade agreements. Unpublished doctoral dissertation, West Virginia University. 
Eskeland, G. S., \& Harrison, A. E. (1997). Moving to greener pastures? Multinationals and the pollution haven hypothesis (Working Paper Series No. 1744). Washington, DC: World Bank.

Feldman, S., Soyka, P. A., \& Ameer, P. (1996). Does improving a firm's environmental management system and environmental performance result in a higher stock price? Washington, DC: ICF Kaiser International.

Ferrantino, M. (1997). International trade, environmental quality and public policy. World Economy, 20(1), 43-72.

*Florida, R., \& Davison, D. (2001). Gaining from green management: Environmental management systems inside and outside the factory. California Management Review, 43(3), 64-84.

Gallarotti, G. M. (1995). It pays to be green: The managerial incentive structure and environmentally sound strategies. Columbia Journal of World Business, 30(4), 38-58.

General Motors. (2002). Corporate responsibility and sustainability report 2001-02. Retrieved September 19, 2003, from http://www.gm.com/company/gmability/ sustainability/reports/02/home.html.

Ghoshal, S., \& Nohria, N. (1993). Horses for courses: Organizational forms for multinational corporations. Sloan Management Review, 34(2), 23-34.

Grant, R. M. (1995). Contemporary strategy analysis: Concepts, techniques, applications (2nd ed.). New York: Blackwell.

Hamilton, J. (1995). Pollution as news: Media and stock market reactions to the Toxic Release Inventory Data. Journal of Environmental Economics and Management, 28, 98113.

Hart, S. L. (1995). A natural-resource-based view of the firm. Academy of Management Review, 20(4), 986-1002.

Hart, S. L., \& Ahuja, G. (1996). Does it pay to be green? An empirical examination of the relationship between emission reduction and firm performance. Business Strategy and the Environment, 5, 30-37.

Haveman, H. A. (1993). Follow the leader: Mimetic isomorphism and entry into new markets. Administrative Science Quarterly, 38, 593-627.

Hill, C. W. L. (2003). International business: Competing in the global marketplace (4th ed.). Boston: McGraw Hill.

Hoffman, A. (1997). From heresy to dogma: An institutional history of corporate environmentalism. San Francisco: New Lexington.

Hoffman, A. J. (1999). Institutional evolution and change: Environmentalism and the U.S chemical industry. Academy of Management Journal, 42(4), 351-371.

Hoffman, A. J. (2001). Linking organizational and field-level analyses: The diffusion of corporate environmental practice. Organization \& Environment, 14(2), 133-156.

ICI. (2003). Sustainability policy statement by Dr. Frank Rose. Retrieved October 3, 2003 , from http://www.ici.com/icishe/2002/pages/approach/global_policy/frank_rose_ intro.htm.

International Institute for Sustainable Development. (2001). Environmental protection and business competitiveness, summary paper (Prepared for The Public Policy Forum). Retrieved September 29, 2003, from http://www.ppforum.com/ow/ow_p_03_ 2001A.pdf.

Jennings, P. D., \& Zandbergen, P. A. (1995). Ecologically sustainable organizations: An institutional approach. Academy of Management Review, 20, 1015-1052.

Johnson \& Johnson. (2001). Corporate environmental report. Retrieved Febuary 12, 2001, from http://www.jnj.com/community/environment/publications/2001_environ_part1.pdf;jsessionid=TQMTBQ23TOQBOCQPCB3SU0A. 
Kappas, P. (2000). The impact of chemical industry self-regulation (Working Paper). Brem Graduate School of Management, University of California Santa Barbara.

Khanna, M., \& Anton, W. Q. (2001). Corporate environmentalmanagement: Regulatory and market-based incentives. Paper presented at the U.S. EPA Beyond Compliance Conference, Washington, DC.

Klassen, R. D., \& McLaughlin, C. P. (1996). The impact of environmental management on firm performance. Management Science, 48(2), 1199-1215.

Klassen, R. D., \& Whybark, D. C. (1999). The impact of environmental technologies on manufacturing performance. Academy of Management Journal, 42(6), 599-615.

Kostova, T., \& Zaheer, S. (1999). Organizational legitimacy under conditions of complexity: The case of the multinational enterprise. Academy of Management Review, 24(1), 64-81.

Kreitz, K. (2002). Anheuser Busch's special brew: Continuous environmental improvement. Retrieved August 16, 2003, from http://www.greenbiz.com/news/news_third.cfm?/ NewsID=21046.

Levitt, T. (1983). The globalization of markets. Harvard Business Review, 61(3), 92-102.

Lewis, G. J., \& Harvey, B. (2001). Perceived environmental uncertainty: The extension of Miller's Scale to the natural environment. Journal of Management Studies, 38(2), 201235.

Leonard, H. J. (1988). Pollution and the struggle for the world product. Cambridge, UK: Cambridge University Press.

Letchumanan, R. L., \& Kodama, F. (2000). Reconciling the conflict between the "pollution haven" hypothesis and an emerging trajectory of international technology transfer. Research Policy, 29(1), 59-79.

Low, P., \& Yeats, A. (1992). Do “dirty" industries migrate? In Patrick Low (Ed.), International trade and the environment. Washington, DC: World Bank.

Lucas, R. E. B., Wheeler, D., \& Hettige, H. (1992). Economic development, environmental regulation and the international migration of toxic industrial pollution, 1960-1988. In Patrick Low (Ed.), International trade and the environment. Washington, DC: World Bank.

Luo, Y. (1999). Entry and cooperative strategies in international business expansion. Westport, CT: Quorum Books.

Magretta, J. (1997). Growth through global sustainability: An interview with Monsanto's CEO, Robert B. Shapiro. Harvard Business Review, 75(1), 78-88.

Mani, M., \& Wheeler, D. (1998). In search of pollution havens: Dirty industry in the world economy, 1960-1995. Journal of Environment and Development, 7(3), 215-247.

Meyer, J. W., \& Scott, W. R. (1983). The organization of societal sectors. In J. Meyer \& W. R. Scott (Eds.), Organizational environments: Ritual and rationality (pp. 129-154). Beverly Hills, CA: Sage.

Miles, M. P., Munilla, L. S., \& McClurg, T. (1999). The impact of ISO 14000 environmental management standards on small and medium sized enterprises. Journal of Quality Management, 4(1), 111-123.

Motorola. (2003). Motorola's environmental management system. Retrieved September 20, 2003, http://www.motorola.com/EHS/environment/management/

Nehrt, C. (1998). Maintainability of first mover advantages when environmental regulations differ between countries. Academy of Management Review, 23(1), 77-97.

Newmont. (2003). Newmont mining corporate webpage, sustainability discussion. Retrieved September 24, 2003, http://www.newmont.com/en/social/sustainable/ index.asp.

Oliver, C. (1991). Strategic responses to institutional processes. Academy of Management Review, 16(1), 145-179. 
Ouchi, W. J. (1980). Markets, bureaucracies, and clans. Administrative Science Quarterly, 25(1), 129-149.

Perlmutter, H. (1969). The tortuous evolution of the multinational corporation. The Columbia Journal of World Business, 4, 9-18.

Porter, M. E., \& van der Linde, C. (1995). Toward a new conception of the environmentcompetitiveness relationship. Journal of Economic Perspectives, 911, 97-118.

Prahalad, C. K., \& Doz, Y. (1987). The multinational mission: Balancing local demands and global vision. New York: Free Press.

Pugh, D. S., Hickson, D. J., Hinings, C. R., and Turner, C. (1968). The dimensions of organization structure. Administrative Science Quarterly, 13, 56-105.

Reilly, W. K. (1990). The green thumb of capitalism: The environmental benefits of sustainable growth. Policy Review, 54, 16-21.

Rondinelli, D. A., \& Vastag, G. 1996. International environmental standards and corporate policies: An integrative framework. California Management Review, 39(1), 106-122.

Rugman, A., \& Verbeke, A. (1998a). Corporate strategies and environmental regulations: An organizing framework. Strategic Management Journal, 19, 363-375.

Rugman, A., \& Verbeke, A. (1998b). Corporate strategy and international environmental policy. Journal of International Business Studies, 29(4), 819-833.

Rugman, A., \& Verbeke, A. (2002). Six cases of corporate strategic responses to environmental regulation. European Management Journal, 18(4), 377-385.

Russo, M. V., \& Fouts, P. A. (1997). A resource-based perspective on corporate environmental performance and profitability. Academy of Management Journal, 40(3), 534-559.

Shaft, T. M., Ellington, R. T., Meo, M., \& Sharfman, M. P. (1997). A framework for information systems in life-cycle oriented environmental management. Journal of Industrial Ecology, 1(2), 135-148.

Shaft, T. M., Sharfman, M. P., \& Swahn, M. (2002). Using inter-organizational information systems to support environmental management efforts at ASG. Journal of Industrial Ecology, 5(4), 95-115.

Sharfman, M. P., Ellington, R. T., \& Meo, M. (1997). The next step in becoming green: Lifecycle oriented environmental management. Business Horizons, 40(3), 13-22.

Sharfman, M. P., Ellington, R. T., \& Meo, M. (1999). Conoco and the vapor recovery project: Using innovation to preserve autonomy. Journal of Industrial Ecology, 3(1), 93-110.

Sharfman, M. P., Wolf, G., Chase, R. A., \& Tansik, D. A. (1988). The antecedents of organizational slack. Academy of Management Review, 13(4), 601-614.

Sharma, S. (2000). Managerial interpretations and organizational context as predictors of corporate choice of environmental strategy. Academy of Management Journal, 43(4), 681-697.

Starik, M., \& Rands, G. P. (1995). Weaving an integrated web: Multilevel and multisystem perspectives of ecologically sustainable organizations. Academy of Management Review, 20(4), 908-935.

Steger, U. (1996). Managerial issues in closing the loop. Business Strategy and the Environment, 5, 252-268.

Steele. (2002). Carl Ware opening remarks: The new global corporate citizenship, Steele Communications, GEMI annual meeting. Retrieved September 29, 2003, from http:// www.steeleweb.com/graphics/gemi2002/PlenaryOpen/CWareKeyNote.pdf.

Walter, I. (1982). Environmentally induced industrial relocation to developing countries. In S. J. Rubin \& T. R. Graham (Eds.), Environment and trade. Montclair, NJ: Allanheld \& Osmun.

Van Maanen, J., \& Schein, E. H. (1979). Toward a theory of organizational socialization. In B. M. Staw (Ed.), Research in organizational behavior. Greenwich, CT: JAI Press. 
Volvo. (2003). Volvo values. Retrieved July 11, 2003, from http://www.volvo.com/group/ global/en-gb/Volvo+Group/ourvalues/.

Mark P. Sharfman is an associate professor of strategic management in the Division of Management of the Michael F. Price College of Business at the University of Oklahoma. He received his Ph.D. from the University of Arizona. His research on environmental management, corporate social performance, and strategic management has appeared in the Academy of Management Journal, Academy of Management Review, Business \& Society, Business Horizons, Corporate Environmental Strategies, Decision Sciences, Journal of Business Ethics, Journal of Corporate Citizenship, Journal of Industrial Ecology, Journal of Management, Journal of Management Studies, Pollution Prevention Review, and Strategic Management Journal. His research has been supported through grants from the U.S. Environmental Protection Agency and the U.S. National Science Foundation. He can be reached at Msharfman@ou.edu.

Teresa M. Shaft is an assistant professor of management information systems in the Division of Management Information Systems of the Michael F. Price College of Business at the University of Oklahoma. She received her Ph.D. from the Pennsylvania State University. Her research on the cognitive processes of computer programmers, environmental information systems, and environmental management has been published in Behavior and Information Technology, Business \& Society, Computers in Human Behavior, Data Base, International Journal of Environmentally Conscious Manufacturing, International Journal of Software Engineering and Knowledge Engineering, Information Systems Research, Journal of Industrial Ecology, and Journal of Management Information Systems. Her research has been supported by the National Science Foundation. She can be reached atTshaft@ou.edu.

Laszlo Tihanyi is an assistant professor of management at the Michael F. Price College of Business, University of Oklahoma. He received his Ph.D. from Indiana University. His research interests include international diversification, the effects of corporate governance on firm international strategies, and organizational adaptation in transition economies. His work has appeared in the Academy of Management Journal, Business \& Society, Journal of Management, and Strategic Management Journal. He can be reached at ltihanyi@ou.edu. 